\title{
EATING AND DRINKING IN THE RESURRECTION BODY ${ }^{1}$
}

\author{
F. S. Mulder \\ (ferdiemulder@gmail.com)
}

This thesis tests the claims that a reception history approach within New Testament studies can assist in i) evaluating and judging interpretations; ii) identifying unresolved problems; iii) asking fresh, new, penetrating questions, and ultimately; iv) providing the materials that help us journey on the continuous quest for theological truth.

Focussing on a number of passages in the NT dealing with the resurrection of Jesus and believers, which have been the source of much disagreement throughout church history, we are guided by four research questions.

Main Research Question: Can a new reception history spanning from the early church until modern times contribute towards better understanding and providing new insights into debates over pluriformity and coherence in relation to the resurrection of Jesus and believers in Paul and the canonical Easter narratives?

Sub-Question A: Can such a reception history assist in identifying significant and previously unnoticed problems?

Sub-Question B: Can an extensive reception history of these problems help us better understand and interpret them?

Sub-Question C: Can reception history assist in addressing these issues in a problem-orientated exegetical study?

We follow three different angles to reception history that make up Part I, II, and III respectively. Part I deals with the main research question and sub-question A. Part II addresses sub-question B, and Part III sub-question $\mathrm{C}$.

In Part I, we provide a new reception history of pluriformity and coherence in relation to debates over the resurrection of Jesus from the

1 F.S. Mulder, 'Reception History and the Interpretation of New Testament Texts: Eating and Drinking in the Resurrection Body (1 Corinthians 6:13a and Luke 24:41-43)' (PhD thesis, Radboud University, Nijmegen, 2016). 
early church to modern times, focussing in on a cluster of canonical Easter texts emphasising the bodily nature of the resurrection of Jesus (e.g. Matt. 28:9; Luke 24:39; John 20:20-27) and also contested Pauline texts such as 1 Cor. $15: 4,37,44$, and 50 . We identify a number of possibly better understandings and new insights. In addition to pluriformity between the four Easter narratives and Paul, there are some key points of coherence in the midst of their differences.

We identify significant problems between 1 Cor. 6:13a and Luke 24:41-43 in the work of Porphyry, the third century neo-Platonic pagan critic, exploring its significance and the lack of attention to them in modern resurrection scholarship. According to Porphyry, not only is there a contradiction between 1 Cor. $6: 13 \mathrm{a}$ and a Jesus who ate and drank after his resurrection (Luke 24:41-43; Acts 1:4; 10:41); in consequence of this contradiction, the risen Jesus eating and drinking 'is not believable, or he pretended to do so'.

We highlight the reality that a large majority of modern 1 Corinthians specialists argue that Paul agrees with his opponents that

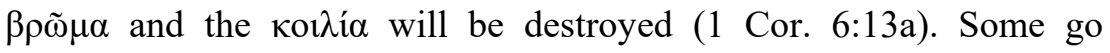
further, arguing resurrection bodies will not posses bodily organs and the capability of eating and drinking, aligning the latter with such texts as Rom. 14:17; 1 Cor. 8:8; 15:44-50 and Luke 20:36 (// Mark 12:25; Matt. 22:30). We demonstrate how these expositions can be in tension with Luke 24:41-43, and eschatological banquet traditions (cf. Isa. 25:6-9; Luke 22:16, 18, 30).

In Part II we embark on a detailed reception history study of 1 Cor. 6:13a and Luke 24:41-43 in the work of a specially selected group of Patristic, Medieval, Protestant, Catholic, and post-Enlightenment historical-critical theologians, who engage with these texts. They are Irenaeus, Tertullian, Augustine, Clement and Origen of Alexandria, John Chrysostom, Thomas Aquinas, John Trapp, William Burkitt, John Gill, Matthew Poole, John Calvin, Matthew Henry, Willi Marxsen, Alexander J. M. Wedderburn, Gerald O'Collins, Murray J. Harris, N. T. Wright and J. A. Schep. Our chapters break new ground and expose previously unnoticed problems. We identify and weigh at least three broad schools of thought:

1) Western theologians' insistence that the post-resurrection Jesus

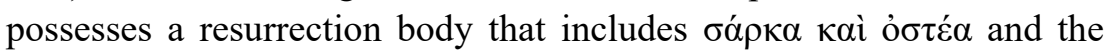
ability to eat (Luke 24:39-43) is contradicted by the acceptance that $\beta \rho \tilde{\omega} \mu \alpha$ and $\kappa o เ \lambda i \alpha$ will be destroyed and excluded from the resurrection 
body (1 Cor. 6:13-14). Attempts to reconcile 1 Cor. 6:13a with Luke 24:41-43, proposing that not the substance of the кoi $\lambda i \dot{\alpha} \alpha$ but its needs will be destroyed are unconvincing.

2) Eastern theologians often suggest resurrection bodies will be sexless and unable to eat and drink (1 Cor. 6:13a; cf. 1 Cor. 15:37-50; Luke 20:36 etc.). The material demonstration in Luke 24:39-43 was a temporary accommodation, after which the risen Jesus returned to his immaterial body in heaven. Our preference for the Western view that change and transformation did not result in the risen Jesus abandoning

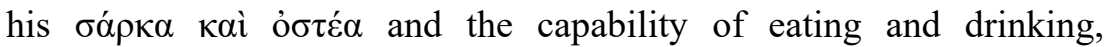
reintroduces problems with 1 Cor 6:13a.

3) Reminiscent of Porphyry, post-Enlightenment historical-critical studies argue that Luke 24:39-43 is a later legendary and anti-Docetic development, on the basis of 1 Cor. 6:13a.

Part II demonstrates that the inability to provide a persuasive and alternative exposition of 1 Cor. 6:13a contributes to the legitimacy and staying power of claims that Luke 24:41-43 is i) unbelievable; ii) Jesus pretended to eat; and iii) represents a later legendary and anti-Docetic development. It also feeds into a long history of Platonic allegorisation of Jesus's prophecies that he will eat and drink in the kingdom with his disciples (Luke 22:16-30), conflicting with recent work on new creation and the eschatological banquet.

Incorporating reception history insights in a problem-orientated exegetical approach, Part III offers a fresh exegesis of 1 Cor. 6:12-13a. We explore three significant issues in modern scholarship of 1 Cor. 6:12-14: i) a near perfect parallelism in verses 13-14; ii) whether there are Corinthian slogans in verses 12-13 or not; and iii) how Paul's views of the resurrection body should be interpreted in verses 13a-14. The most extensive section comprises five influential texts, that is, Rom. 14:17; 1 Cor. 8:8; 1 Cor. 15:44, 50; Luke 20:36, in modern times relied upon as hermeneutical lenses for the view that the second part of 1 Cor. 6:13a is Paul's response to a Corinthian slogan. In addition to negative arguments, we attempt to break new ground. For instance,

a) Focussing on the neutrality of food and eating in 1 Cor. 8:8, we explore the eschatological significance of sins associated with eating and drinking (cf. 1 Cor 5:11; 6:9-10; 10:7-8; 15:32-34).

b) We offer a new mediated approach to continuity and

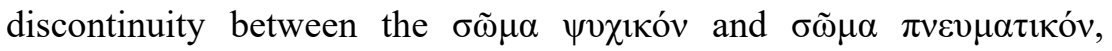


moving beyond Eastern 'personal identity' and Western 'material identity' (cf. 1 Cor. 15:35-44).

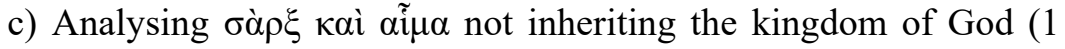
Cor. 15:50), we offer an alternative to an immaterial / non-physical resurrection body (Eastern tradition) and a fleshly resurrection body (Western tradition). In an experimental excursus we explore the possible significance of the eschatological banquet background of 1 Cor. 15:54 (cf. Isa. 25:6-9) for situating and interpreting 1 Cor 15:42-55.

d) Zooming in on Luke 20:36, we develop a middle position rejecting both Eastern views of a sexless resurrection body, and a Western fleshly resurrection body. In an extensive experimental excursus, we develop a new reading strategy between Luke 20:36; Luke 22:16, 18, 30, and Luke 24:41-43. This is followed by a new approach to the presence of the risen Christ in the Lord's Supper, moving beyond traditional Catholic, Lutheran, and Reformed views.

In light of negative and positive evidence presented, we argue that none of these texts can be used as hermeneutical lenses or supporting texts for the claim that the second part of 1 Cor. 6:13a is Paul's response to a Corinthian slogan.

This is followed by a discussion of the view that the whole of 1 Cor. 6:13a is a Corinthian slogan. On contextual grounds, we propose that the conjunction $\delta \varepsilon$ (in 1 Cor. $6: 13 a$ ) should be translated continuative, which makes it more likely that the whole of 1 Cor. 6:13a represents a Corinthian position Paul cannot accept.

Part VI applies the results of Part III to the problems between 1 Cor. 6:13a and Luke 24:41-43. In Part V we conclude that reception history as an approach within New Testament studies not only contributes substantially, but is in fact indispensable for i) evaluating and judging interpretations; ii) identifying unresolved problems; iii) asking fresh, new penetrating questions, and ultimately; iv) providing the materials that help us journey on the continuous quest for theological truth. 